\title{
THE EFFECTS OF RICE HUSK ASH AND PAPER WASTE ASH AS ADMIXTURE TO SELF COMPACTING CONCRETE
}

\section{PITOYO, SUBANDI, RAFIDAH AZZAHRA, \& VEBRIAN}

Civil Engineering, Universitas Muhammadiyah Kalimantan Timur, Indonesia

\begin{abstract}
The development of concrete from time to time is more advanced, several types of concrete with various uses, one of which is Eco Self Compacting Concrete or commonly called SCC (self-compacting concrete), as well as a mixture of additional materials. from chemicals and materials derived from waste, such as the material we used in this experiment, the material used came from rice husk waste and HVS paper waste, both materials were made to ashes by burning them manually, then ash was sieved. The chemical content contained in rice husk ash has a dominant chemical content of $\mathrm{SiO} 286,91$, and paper waste ash has a dominant chemical content is $\mathrm{CaO} 97,70$. From this previous experiment with the same mixed design without using two ashes, the results obtained are strong press 14, $7 \mathrm{MPa}$, whereas concrete with the addition of rice husk ash and the results of used paper ash at the age of 1 day get a compressive strength of $22.8 \mathrm{MPa}$, while at the age of 28 days in the last experiment produced a compressive strength of $49.6 \mathrm{MPa}$ and in this experiment produced compressive strength of 52.3 there is an additional compressive strength of $2.7 \mathrm{MPa}$. The results of the slump flow on the specimen without using two ashes of $750 \mathrm{~mm}$ while with the addition of the two slumps ashes obtained were 650. The conclusion obtained in this experiment the two ashes we used could be as a mixed paste to make SCC concrete.

KEYWORDS: Scc, Concrete, Admixture, Rha, Paper Ash
\end{abstract}

Received: Jun 09, 2020; Accepted: Jun 29, 2020; Published: Sep 14, 2020; Paper Id.: IJMPERDJUN20201218

\section{INTRODUCTION}

Self-concrete, also known as self-compacting concrete (SCC), is a high flowing, non-segregating concrete that spreads into place, fills the formwork, and encapsulates even the most dense reinforcement, all vibrational vibrations. It is defined as a concrete mix that can be maintained under its weight, with little or no vibration. As a high-performance concrete, SCC provides these attractive benefits while maintaining all the creativity and durability of traditional concrete. Adaptation to traditional mix designs and the use of superplasticizers creates concrete that meets tough performance requirements. If necessary, low doses of viscosity modifiers can eliminate unwanted bleeding and segregation [1]. Incorporation of powders, including additional cementitious materials and fillers, can increase the volume of the paste, thereby increasing deformability, and can also increase the compactness of the paste and the stability of the concrete. Reduced cement content and increased packing density of materials finer than $80 \mu \mathrm{m}$, such as fly ash, etc. Can reduce the water-cement ratio and the demand for high range of water damper (HRWR). This reduction in free water can reduce the viscosity-increasing mixing (VEA) concentration required to ensure proper stability during casting and thereafter until hardening occurs. It has been shown that the total content of fine ("fine", usually sand) aggregates is about $50 \%$ of the total aggregate according to the SCC mixture. [2]. The composition of SCC consists of mortar and paste, the paste usually used is fly ash, 
and. [3]. The composition of the SCC can be seen in Figure 1.
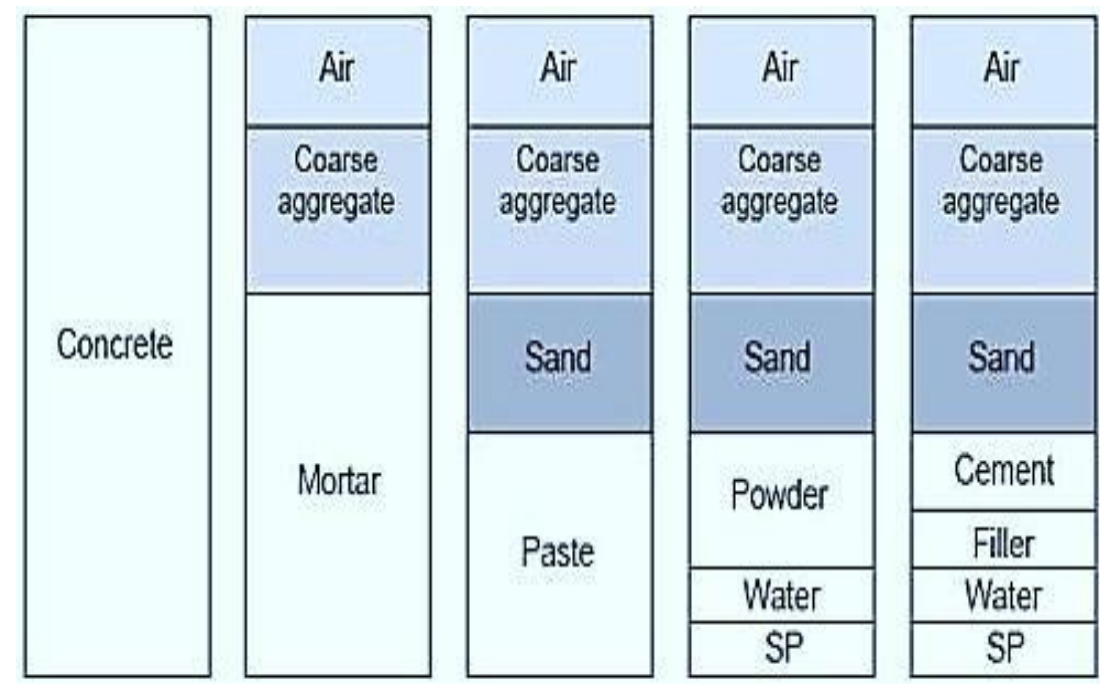

Figure 1 Composition of the SCC.

The use of rice husks as a substitute for sand to make lightweight concrete has been carried out and coarse aggregate from ironwood, the results of these studies produce lightweight concrete with a compressive strength of more than $22 \mathrm{MPa}$ [4], and the use of rice husk charcoal as an added material to strengthen concrete performance [5], [6]. Rice husk is a waste from the results of processing unhulled rice into rice, rice husk ash has been conducted a lot of research related to concrete which has various functions, some as admixture, a partial substitute for cement, and others. The use of rice husk ash as a partial replacement of cement has been carried out, among others [7], [8], [9] Making concrete by adding rice husk ash and superplasticizer can increase the strength of the concrete [10], Experiments on the use of fly ash and rice husk ash in the manufacture of high-quality concrete are also able to provide additional strength that reaches $76 \mathrm{MPa}$ [11]. The chemical content contained in rice husk ash with the greatest chemical element is $\mathrm{SiO} 2$ [12] where $\mathrm{SiO} 2$ is also present in the chemical elements in ordinary cement, the chemical content of rice husk ash is presented in table 1.

Table 1: Rice Husk Ash Chemistry

\begin{tabular}{|c|c|c|c|c|c|c|c|}
\hline Chemistry & $\mathrm{SiO2}$ & $\mathrm{Al}_{2} \mathbf{O}_{3}$ & $\mathrm{Fe}_{2} \mathbf{O}_{3}$ & $\mathbf{C a O}$ & $\mathbf{M g O}$ & $\mathrm{Na}_{2} \mathbf{O}$ & $\mathrm{K}_{2} \mathbf{O}$ \\
\hline Composition (\%) & 86.91 & 0.5 & 0.87 & 1.04 & 0.85 & 0.69 & 3.16 \\
\hline
\end{tabular}

The use of paper waste into the world into civilian techniques has begun to be widely practiced, such as making panels for furniture using paper waste raw materials from newspapers [13], using paper pulp and fly ash waste in making bricks with a mixture of paper pulp waste as large as $50 \%$ of the weight of sand and fly ash by $10 \%$ produces a concrete block's compressive strength of $47.0474 \mathrm{Kgf} / \mathrm{cm} 2$, and the use of paper ash and rice husk ash as powder in making self compacting concrete (SCC) The chemical content of paper ash according to [14] contains the dominant chemical content is $\mathrm{CaO}$, the chemical content of ash from paper waste can be seen in table 2.

Table 2: Chemical Content of Paper Ash

\begin{tabular}{|c|c|c|c|c|c|c|c|}
\hline Chemistry & $\mathbf{S i O 2}$ & $\mathbf{A l}_{2} \mathbf{O}_{3}$ & $\mathbf{F e}_{2} \mathbf{O}_{3}$ & $\mathbf{C a O}$ & $\mathbf{M g O}$ & $\mathbf{N a}_{2} \mathbf{O}$ & $\mathbf{K}_{2} \mathbf{O}$ \\
\hline Composition (\%) & 2,63 & 0,60 & 0,71 & 97,70 & 1,19 & 1,22 & 0,49 \\
\hline
\end{tabular}


The composition of SCC paste consists of powder, water, and superplasticizer, the powder itself consists of cement, and filler. The fillers used in SCC concrete are usually fly ash and silica fume. Fly ash and silica fume can only be found in a few areas, besides that the price is also quite high, in this study trying to replace fly ash and silica fume using rice husk waste and waste from paper made of ash as a substitute for fly ash and silica fume.

This study aims to find alternatives to fillers in the form of fly ash and silica fume with rice husk ash and paper ash, so that the wider community can use alternative materials to substitute fillers in SCC concrete. In addition, it is also used to utilize rice husk waste and paper waste, so that both waste can be useful.

\section{MATERIALS AND METHODS}

In this research, the material innovation we use is waste from processing unhulled rice into rice (rice husks), and paper waste of the HVS type. We take the rice husks from the rice milling factory in the campus area, which is located in the Bengkuring area, approximately $3 \mathrm{~km}$ from our campus, while the paper waste is taken from the paper warehouse belonging to the Muhammadiyah University campus of East Kalimantan. The selection of rice husks is based on the large chemical content of $\mathrm{SiO} 2$ that comes from the ash. Meanwhile, the selection of paper waste was due to our previous research that the chemical content of ash from HVS paper waste contained high $\mathrm{CaO}$ chemical elements. As is known, the chemistry in cement contains the chemical elements $\mathrm{SiO} 2$ and $\mathrm{CaO}$. The super plasticizer used is master glenium sky 8852 [15].

Our innovative material processing includes making rice husks to ashes, by burning the rice husks manually. Making rice husk ash by manual combustion takes \pm 5 hours with an average heat of $450^{\circ}$, after the rice husk has turned into ash, we sift the ash with a sieve sieve no. 150. Likewise, the processing of ash from paper waste. HVS, we burn the paper manually in a drum. The paper is put in a drum and then burned, the burning time for paper with a weight of $5 \mathrm{~kg}$ takes \pm 25 minutes with the resulting heat of $750^{\circ}-800^{\circ}$, after the paper becomes ash, the paper ash is sieved using a sieve sieve no. 150 .

Testing of density, friability, specific gravity, gradation, wear, water absorption, sludge content, and organic content is carried out on the materials used, among others:

- Coarse aggregate ex. Hammer testing method using SNI and ASTM [16],[17],[18].

- $\quad$ Fine aggregate ex. Hammer. using SNI and ASTM testing methods [17],[18],[19].

In this mixed design using an experimental method based on an experiment we did before, the water ratio was 0.322 , with a slump flow plan of $600 \mathrm{~mm}-750 \mathrm{~mm}$, the results of the mixed design can be seen in table 3 .

Table 3: Mix Design

\begin{tabular}{|c|c|c|c|c|c|c|c|}
\hline & $\begin{array}{c}\text { Water } \\
(\mathbf{K g})\end{array}$ & $\begin{array}{c}\text { Cement } \\
(\mathbf{K g})\end{array}$ & $\begin{array}{c}\text { Coarse } \\
\text { Aggregate } \\
(\mathbf{K g})\end{array}$ & $\begin{array}{c}\text { Fine } \\
\text { Aggregat } \\
(\mathbf{K g})\end{array}$ & $\begin{array}{c}\text { Rice Husk } \\
\text { Ash 2,5\% } \\
(\mathbf{K g})\end{array}$ & $\begin{array}{c}\text { Husk Ash } \\
\text { Paper 7,5 \% } \\
(\mathbf{K g})\end{array}$ & $\begin{array}{c}\text { Master } \\
\text { Glenium } \\
(\mathbf{K g})\end{array}$ \\
\hline $1 \mathrm{~m}^{3}$ & 144,6 & 449 & 567 & 1108,4 & 11,225 & 33,675 & 2,373 \\
\hline
\end{tabular}

The mix design in the table above rice husk ash and paper ash replace the use of fillers in the form of fly ash and silica fume, the resulting compressive strength results in mix design using fly ash and silica fume produces a compressive strength of $49.6 \mathrm{MPa}$ at the age of 28 days. 
The specimen in this study is a cylinder with a diameter of $15 \mathrm{~cm}$ and a height of $30 \mathrm{~cm}$. A total of 12 pieces were made, which were tested at the age of 1, 7, 14, and 28 days. Fresh concrete testing includes Slump flow, T50, L Box, and V Tunel. And compressive strength testing.

\section{RESULTS AND DISCUSSIONS}

\section{Result}

From the results of material testing, the results are presented in table 4 .

Table 4: Material Testing Results

\begin{tabular}{|c|l|c|c|c|c|}
\hline No & \multicolumn{1}{|c|}{ Material } & Coarse Aggregate & Sand & Rice Husk Ash & Husk Ash Paper \\
\hline 1 & Solid fill weight & 1485,90 & 1631,29 & 444,3 & 443,5 \\
\hline 2 & Crumbly fill weight & $1.408,30$ & $1.476,61$ & 442,9 & 441,8 \\
\hline 3 & Specific gravity & 2,51 & 2,473 & 2,78 & 2,59 \\
\hline 4 & Water Absorption & 2,04 & 0.012 & 26,58 & 29,76 \\
\hline 5 & Fine grain modulus & 7,67 & 3.16 & - & - \\
\hline 6 & Abrasion & 32,826 & - & - & - \\
\hline 7 & Organic matter & - & 1 & - & - \\
\hline 8 & Sludge content & 1,58 & 0,31 & - & - \\
\hline
\end{tabular}

From the results of testing fresh concrete is presented in table 5. The compressive strength test is presented in table 6

Table 5

\begin{tabular}{|c|c|c|c|}
\hline Slump Flow (mm) & T50 (detik) & L Box $(\mathbf{c m})$ & V Tunel HR1/HR2 \\
\hline 750 & 2,87 & 52,1 & 0,89 \\
\hline
\end{tabular}

Table 6

\begin{tabular}{|c|c|c|}
\hline Age (days) & Weight (kg) & Compressive Strength (MPa) \\
\hline 1 & 11,91 & 22,8 \\
\hline 7 & 11,69 & 32,6 \\
\hline 14 & 11,64 & 42,8 \\
\hline 28 & 11,53 & 52,3 \\
\hline
\end{tabular}

Seen in table 6 , the test results from the age of 1 day to the age of 28 days experienced a steady increase in strength. Figure 1. graph of the increase in the compressive strength of concrete.

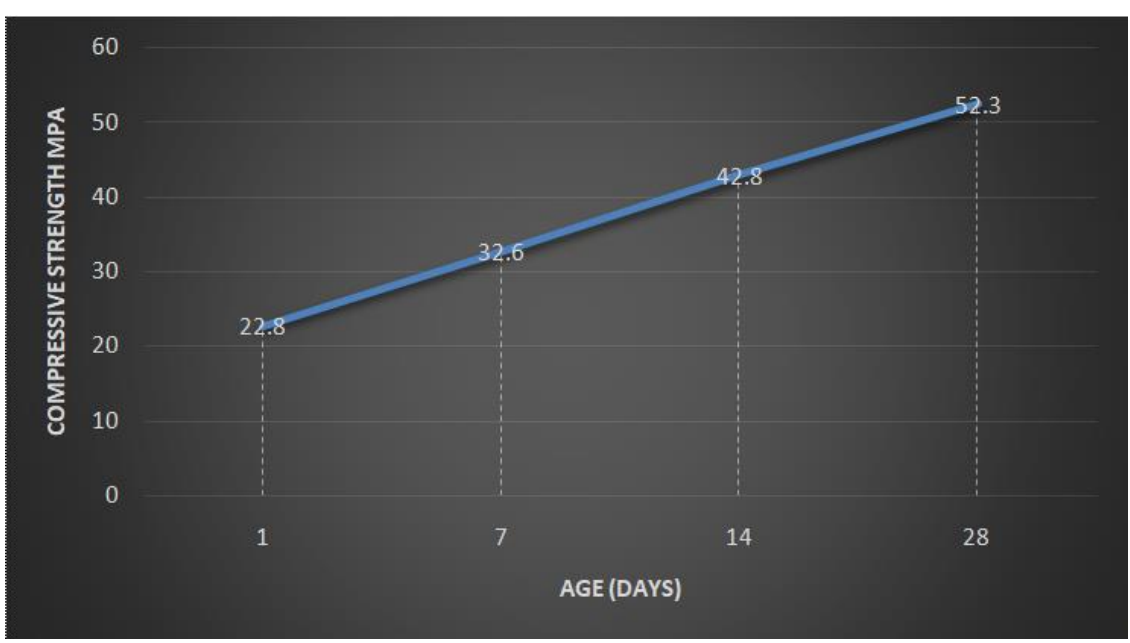

Figure 1: Development of the Compressive Strength of Concrete. 


\section{DISCUSSIONS}

In this study, 12 specimens were made. This study used additional materials in the form of rice husk ash and paper waste ash as a mixture. And Superplasticizer using Master Glenium SKY 8851, as much as $1 \%$ by weight of cement. Based on the design of the mix design that we made using two ashes, this can increase the strength of the concrete, this is based on a comparison with the test specimens we made previously, where the specimens we made previously did not use rice husk ash and ash paper, tested at 1 day of age. in the previous experiment only produced the compressive strength of $14.7 \mathrm{MPa}$ concrete. Meanwhile, with the addition of rice husk ash and paper ash the compressive strength test results at the age of 1 day resulted in a compressive strength of $22.8 \mathrm{MPa}$. Likewise, at the age of 7, 14, and 28 days of concrete, all of the specimens produced compressive strength above the average compressive strength using fly ash and silca fume. The addition of rice husk ash $(\mathrm{SiO} 2)$ and paper waste ash $(\mathrm{CaO})$ can react with silica oxide $(\mathrm{SiO} 2), \mathrm{Al} 2 \mathrm{O} 3$ and $\mathrm{FeO} 3$ to give tobermorite results, so that it can increase the strength and density of concrete.

That pozolan binds free lime in concrete and forms the same hydrated calcium silicate as hydrated cement. The utilization of these two wastes can increase the strength of the SelfCompacting Concerete Concrete compared to the concrete without the two ashes that we use. in addition to the positive impacts caused by the use of this waste in social, economic and environmental aspects, as we have stated in the previous chapter.

\section{CONCLUSIONS}

- From the results of the research carried out, the use of substitute materials for SCC concrete paste using rice husk ash and paper ash was able to replace the commonly used pasta, namely fly ash and silica fume.

- $\quad$ Besides being a substitute for the two waste materials used, it also provides additional strength to SCC concrete. So that rice husk waste and paper waste made of ash can be used as a building block for SCC concrete

\section{REFERENCES}

1. N. R. M. C. Association, "Self Consolidating High Performance Concrete - SCC Self Consolidation and Highly Flowable Concrete,” 2011. [Online]. Available: http://www.selfconsolidatingconcrete.org/. [Accessed: 01-Sep-2019].

2. P. L. Domone, "Department of Civil, Environmental and Geomatic Engineering Proportioning of self-compacting concretethe UCL method P Domone November 2009," Dep. Civ., Environ. Geomat. Eng., no. November 2009, p. 30, 2010.

3. H. J. H. Brouwers and H. J. Radix, “Erratum to 'Self-Compacting Concrete: Theoretical and experimental study' [Cement and Concrete Research 35(11) (2005) 2116-2136], ” Cem. Concr. Res., vol. 37, no. 9, p. 1376, Sep. 2007.

4. Subandi, A. A. Arha, C. Kusuma, and M. N. Asnan, "Utilization of Ironwood Waste and Husk Charcoal to Produce Lightweight Concrete, "' Int. J. Civ. Eng., vol. 6, no. 7, pp. 17-22, Jul. 2019.

5. Subandi, T. Nasrulah, A. A. Arha, I. Zulkarnain, and M. N. Asnan, "Effect of Addition of Rice Husk Charcoal on Concrete Compressive Strength," Int. J. Eng. Adv. Technol., vol. 8, no. 6, pp. 4951-4955, Aug. 2019.

6. Subandi, C. Kusuma, M. N. Asnan, M. Damaiyanti, and S. Yatnikasari, "Manufacture of Concrete with Artificial Sand from Rice Husk Waste, ”'Int. J. Recent Technol. Eng., vol. 8, no. 3, pp. 1670-1673, Sep. 2019.

7. A. Kumar, A. K. Tomar, S. Kishor Gupta, and A. Kumar, “Replacement of Cement in Concrete with Rice Husk Ash,” Int. J. Civ. Eng., vol. 3, no. 7, pp. 127-129, Jul. 2016. 
8. S. Ghosal and S. Moulik, "Use of Rice Husk Ash as Partial Replacement with Cement In Concrete- A Review," Int. J. Eng. Res., vol. 4, no. 9, pp. 506-509, Sep. 2015.

9. A. I. Gupta and A. S. Wayal, "Use of rice husk ash in concrete," IOSR J. Mech. Civ. Eng., vol. 12, no. 4, pp. $29-31,2015$.

10. T. Van Lam, B. Bulgakov, Y. Bazhenov, O. Aleksandrova, and P. N. Anh, "Effect of rice husk ash on hydrotechnical concrete behavior, "IOP Conf. Ser. Mater. Sci. Eng., vol. 365, no. 3, 2018.

11. T. Van Lam, B. Bulgakov, O. Aleksandrova, O. Larsen, and P. Ngoc Anh, "Effect of rice husk ash and fly ash on the compressive strength of high performance concrete," E3S Web Conf., vol. 33, p. 02030, Mar. 2018.

12. C. E. S. Kumar and V. Raju, “A study on replacement of cement with rice husk ash,” Int. J. Civ. Eng. Technol., vol. 8, no. 1, 2017.

13. T. Amelia et al., “Eksperimen Material untuk Mebel dari Limbah Kertas Koran,” vol. 6, no. 2, pp. 572-579, 2018.

14. Subanndi, F. Agustina, Vebrian, and R. Azzahra, "Waste paper ash as additives for high strength concrete mix 45 MPa," Ann. Chim. Sci. des Mater., 2020.

15. "MasterGlenium SKY 8851." [Online]. Available: https://www.master-builders-solutions.com/enid/products/mastergleniumsky/masterglenium-sky-8851. [Accessed: 01-Sep-2020].

16. SNI 03-4804-1998, “Metode Pengujian Bobot Isi dan Rongga Udara dalam Agregat,” Balitbang PU, pp. 1-6, 1998.

17. SNI 03-4142-1995, "Metode Pengujian Jumlah Bahan Dalam Agregat,” vol. 200, no. 200, pp. 1-6, 1995.

18. S. N. I. Astm, “Metode uji untuk analisis saringan agregat halus dan agregat kasar ( ASTM C 136-06, IDT),” 2012.

19. SNI 03-1970-1990, “Metode Pengujian Berat Jenis dan penyerapan air agregat halus,” Bandung Badan Stand. Indones., pp. $1-17,1990$.

20. Aanal Shah\& C.B.Shah, "INFLUENCE OF ALKALINE ACTIVATORS AND TEMPERATURE ON STRENGTH PROPERTIES OF GGBS BASED GEOPOLYMER CONCRETE «, International Journal of Civil Engineering (IJCE), Vol. 6, Issue 3, pp.2128

21. Chirag Garg \& Aakash Jain, «Green Concrete: Efficient \& Eco-Friendly Construction Materials «, IMPACT: International Journal of Research in Engineering \& Technology (IMPACT: IJRET), Vol. 2, Issue 2, pp. 259-264

22. Ahmed M. Emarah, Kamal G. Metwally \& Abdelhamid I. Zaghw, "Comparative Analytical Study of Reinforced Concrete Wall Subjected to Blast Loading Pattern «, BEST: International Journal of Management Information Technology and Engineering (BEST: IJMITE), Vol. 5, Issue 09, pp. 73-78

23. Bismi Varghese \& Nivin Philip, "A Review: Taguchi Experiment Design for Investigation of Properties of Concrete «, International Journal of Civil Engineering (IJCE), Vol. 5, Issue 6, pp.11-16 


\section{AUTHORS PROFILE}

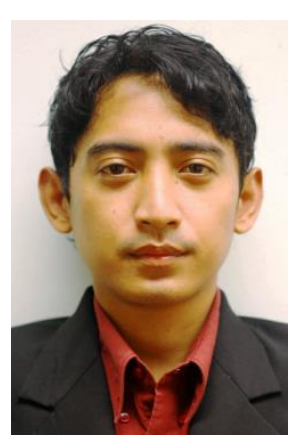

Pitoyo: Department of Civil Engineering, Faculty of Science and Technology Universitas Muhammadiyah Kalimantan Timur. Publication of journal : Inovasi limbah plastik menjadi agregat kasar dalam campuran beton ringan, Garbage transport system in the final shelter city of samarinda with hauled containers system (Hcs).

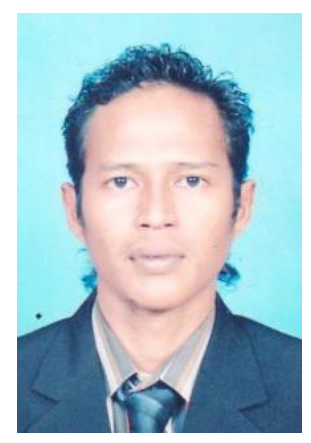

Subandi: Student of the course of Civil Engineering Faculty of Science and Technology Universitas Muhammadiyah Kalimantan Timur, Semester 7. Publication of the journal : Utilization of Ironwood Waste and Husk Charcoal to Produce Lightweight Concrete, Effect of Addition of Rice Husk Charcoal on Concrete Compressive Strength, Manufacture of Concrete with Artificial Sand from Rice Husk Waste, Effect of Additional Fiberglass Fiber on Concrete Performance, Waste Paper Ash as Additives for High Strength Concrete Mix 45 MPa.

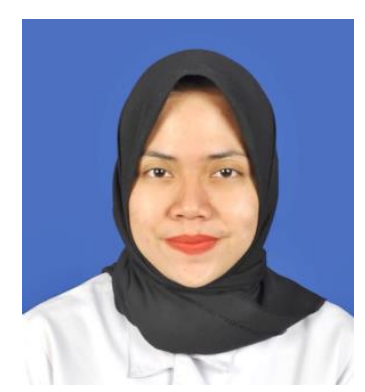

Rafidah Azzahra: Student of the course of Civil Engineering Faculty of Science and Technology Universitas Muhammadiyah Kalimantan Timur, Semester 7. Publication of journal : Inovasi limbah plastik menjadi agregat kasar dalam campuran beton ringan, Utilization of Styrofoam-Matrix for Coarse Aggregate to Produce Lightweight Aggregate Concrete, Effect of Additional Fiberglass Fiber on Concrete Performance, Waste Paper Ash as Additives for High Strength Concrete Mix $45 \mathrm{MPa}$. 
